\title{
Ethnobotanical study and nutrient content of local vegetables consumed in Central Kalimantan, Indonesia
}

\author{
HASTIN E.N.C. CHOTIMAH ${ }^{1, \varphi}$, SUSI KRESNATITA ${ }^{1}$, YULA MIRANDA ${ }^{2}$ \\ ${ }^{1}$ Department of Agronomy, Faculty of Agriculture, Palangkaraya University. Jl. Yos. Sudarso, Palangkaraya 73112, Central Kalimantan, Indonesia. Tel. \\ +62-536-3326196, ’email: hastinwindarto@yahoo.com \\ ${ }^{2}$ Department of Mathematics and Natural Sciences Education, Faculty of Teacher Training Education, Palangkaraya University, Central Kalimantan, \\ Indonesia
}

Manuscript received: 4 May 2013. Revision accepted: 15 May 2013.

\begin{abstract}
Chotimah HENC, Kresnatita S, Miranda Y. 2013. Ethnobotanical study and nutrient content of local vegetables consumed in Central Kalimantan, Indonesia. Biodiversitas 14: 106-111. People in Central Kalimantan consume vegetables collected from the wild or traditionally cultivated. Documentation effort of them is very important because the diversity of local vegetables is threatened with extinction due to the conversion of peat land and forest fires. This study aimed to determine the diversity of local vegetables in Central Kalimantan, its use as a vegetable and nutrient content of some vegetables. The method used was the exploration and interviews. Exploration was carried out in three districts, namely Palangkaraya, Pulang Pisau, and Seruyan. Sampling of plants was done randomly and selectively. Data analysis was performed descriptively. The results showed that we recorded 42 plant species belonging to 30 families. There were many vegetables processing: stir-fry, make into clear soup, a light coconut milk soup, acidic soup, or just consumed as fresh vegetables. Based on the nutritional value, Helminthostachys zeylanica (L.) Hook had a potential to be developed as vegetables or medicinal plant. It had the highest protein, carbohydrate and minerals, namely $\mathrm{P}, \mathrm{Fe}, \mathrm{Na}$ and $\mathrm{K}$ among the vegetables analyzed.
\end{abstract}

Key words: ethnobotany, indigenous vegetables, nutritional value, Central Kalimantan

\section{INTRODUCTION}

Conserving the world's biodiversity is very important to support sustainable living. Kalimantan island is endowed with agro-biodiversity like local vegetables which have high nutritional value, health benefits, income-generation potential, and agronomic advantages that can be exploited. Major constraints that hinder optimal production and utilization of the local vegetables include neglect by stakeholders, lack of quality seed, lack of technical production and utilization packages, and poor marketing channels. Consequently, their potential has not been fully exploited. In this study, the term 'local vegetables' is used to refer to both native and introduced vegetables. Native vegetables are edible plants indigenous to an area, while introduced vegetables are those that have been introduced into a particular area. Introduced vegetables have adapted to local condition after their introduction with the result that they are considered as local or even thought as native (Laker 2007; Dweba and Mearns 2011). It is reported that in Central Kalimantan more than 200 plants are used as local vegetables. Some of them are believed to have properties to maintain a healthy body from disease. In African communities, African indigenous vegetables have been reported to have high nutritional value, where consumption of $100 \mathrm{~g}$ of the vegetables provides over $100 \%$ of the daily requirement of vitamins and minerals and $40 \%$ of proteins (Onyango 2003).

Some local vegetables that are currently found and consumed a lot by people in Central Kalimantan are
Stenochlaena palustris, Ceratopteris thalictroides, Calamus sp., Cnesmone javanica, Nauclea sp. and others (Irawan et al. 2006). Meanwhile research on the utilization of plant fruits and wild vegetables by the Dayak Kenyah of East Kalimantan showed that many species of fruit bearing plants are cultivated by the tribe, but it is not the case with vegetables. The reason is that many wild plants can be utilized for the vegetable, making it less necessary to cultivate. Leaves, shoots and roots of various wild plants can be eaten as a vegetable. Buds and shoots of Cyperus bancanus, shoot of Imperata cylindrica are consumed as fresh vegetables. Young leaves and stems of Cyathea contaminans as well as Diplazium ferns, Nephrolepis bisserata, and Stenochlaena are boiled or pan-fried vegetables and sometimes traditionally cooked in bamboo tubes. Likewise, other species of Zingiberaceae such as Alpinia sp., Kaempferia sp., Nicolaia speciosa are source of vegetables and the preferred flavoring. The tip of the harvested rattan trunk is usually processed by fire until withered, then the tough skin and thorn are peeled. The inside is then used as a vegetable. Likewise, young rattan trunk of Eugeissona utilis, Oncosperma and Pinanga are vegetables usually cooked along with fish (Hendra 2002). In Central Kalimantan, documentation effort is very important because the diversity of local vegetables are threatened with extinction due to land conversion for plantations and transmigration areas. The condition was further exacerbated by the presence of peat forest fires which almost always occur every dry season. This research was intended to conserve local vegetables in Central 
Kalimantan by conducting an initial survey to collect basic information on their nutritional content. The abundance and nutrient information of them are very important for the establishment of baseline information for creating food consumption guidelines for local communities, applying cultivation technology to support the food security, and for determinating the phytochemical and pharmaceutical potential.

\section{MATERIALS AND METHODS}

The objectives of this study were to determine the availability of local vegetables in Central Kalimantan, Indonesia and to assess the current and possible future utilization as a food source. The method used was the exploration and interviews. Exploration carried out in three districts namely Palangkaraya, Seruyan, and Pulang Pisau in Central Kalimantan in the middle of Indonesia
(Figure 1). The Dayaks tribe are natives who inhabit the island of Kalimantan. Literally 'dayak' means the rural community and is a collective term for a variety of ethnic groups, which differ in language, art forms, and many elements of culture and social organization (MacKinnon et al. 2000). They have consumed and taken advantage of local vegetables for generations. Some of the vegetables are not specifically cultivated or grow wild in the forest without human intervention. They can survive in poor soils; require less inputs and resources, chemical fertilizers and pesticide.

Vegetables were sampled randomly and selectively. The sampling included the vegetative parts (shoots, stems and leaves) and the generative (flower, fruit and seeds) as well as other parts such as bulbs and others. Exploration was also done with the interview method. Target informants for the interview per district were ten traditional vegetable traders in market $\mathrm{t}$ and three key informants. The key informants were community leaders and local people

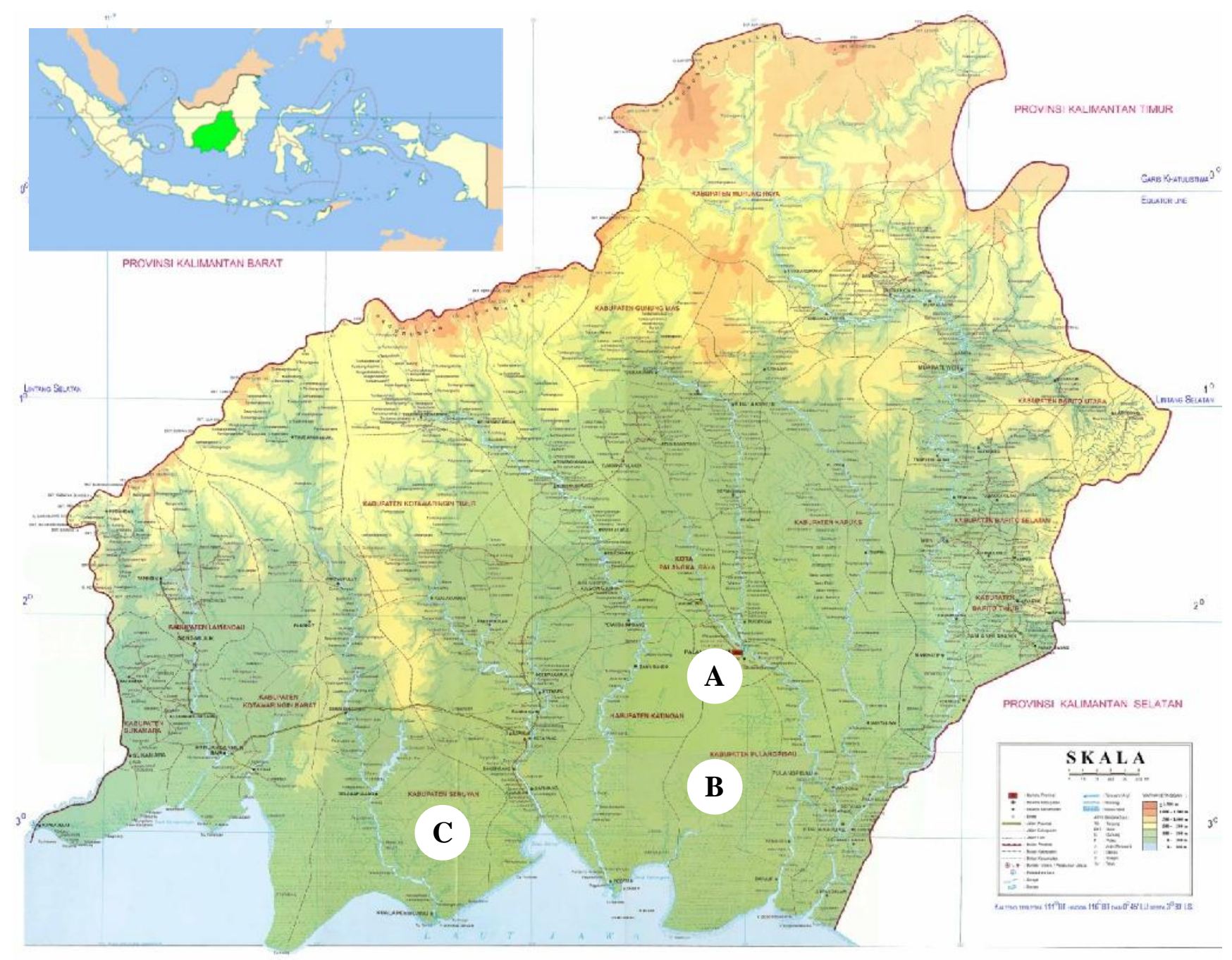

Figure 1. Locations of study in Districts of (A) Palangkaraya, (B) Pulang Pisau, and (C) Seruyan, in Central Kalimantan Province, Indonesia 
who make use of existing local plants around to meet the daily need. Data collected included: name of plant species (local name and scientific name), the parts of plant consumed, method of cooking, natural habitat, the seasonal abundance, and the economic value. Identification was done using the key determination of the book Flora of Java (Backer and Bakhuizen van den Brink 1963; 1965; 1968). Data analysis was performed descriptively. Moisture and ash contents were analyzed by gravimetric methods. Fat was determined by hydrolysis soxhlet methods. Crude protein was estimated by the micro Kjeldahl method. Total protein was calculated by multiplying the evaluated nitrogen by 6.25 . Phosphor content was determined by spectrophotometry, meanwhile $\mathrm{Ca}, \mathrm{Fe}, \mathrm{Na}$ and $\mathrm{K}$ nutrient by AAS (AOAC 1990). Analysis of vitamin C was determined by spectrophotometry.

\section{RESULTS AND DISCUSSION}

\section{Abundance of local vegetables}

From the observation and exploration in traditional markets and in the field 42 species belonging to 30 families of local vegetables have been identified. A list of species and plant parts used are presented in Table 1. There were some vegetables found in the market but not at the site of exploration, and vice versa. Vegetables Ardisia sp. and Lepisanthes alata were not found in traditional markets, but were found at the site of exploration in the District of Seruyan. Ardisia sp. now very rare, while L. alata was found in the vicinity of the riverside. The others found in the market were Ceratopteris thalictroides and Stenochlaena palustris, Curcuma domestica, Helminthostachys zeylanica and various species of mushrooms.

Table 1. List of local species consumed as vegetables in Central Kalimantan

\begin{tabular}{|c|c|c|c|}
\hline Vernacular Name & Latin Name & Family & Part being used \\
\hline Bakung & Crinum asiaticum $\mathrm{L}$. & Amaryllidaceae & Bulb \\
\hline Pisang & Musa paradisiaca $\mathrm{L}$. & Araceae & Flower, fruit \\
\hline Uwei & Calamus sp. L. & Arecaceae & Young shoot \\
\hline Enyoh & Cocos nucifera $\mathrm{L}$. & Arecaceae & Young shoot \\
\hline Undus & Elaeis guineensis_Jacq & Arecaceae & Young shoot \\
\hline Segau & Lactuca virosa L. & Asteraceae & Leave \\
\hline Kulat bitak & Auricularia sp. (Bull.) J.Schrot. & Auriculariaceae & Fruit body \\
\hline Kanas & Ananas comosus Merr & Bromeliaceae & Young fruit \\
\hline Genjer & Limnocharis flava (L.) Buchenau & Butomaceae & Shoot, young leave, flower \\
\hline Mantela & Carica papaya L. & Caricaceae & Flower, fruit, young leaves \\
\hline Kujang & Colocasia esculentum Schott & Colocasiaceae & Runner \\
\hline Tantimun batu & Cucumis sativus L. & Cucurbitaceae & Fruit \\
\hline Tantimun & Cucumis sativus L. & Cucurbitaceae & Young leave \\
\hline Baluh bahenda & Cucurbita moschata Duch & Cucurbitaceae & Flower, fruit, young leave \\
\hline Kanjat & Gymnopetalum cochinense Kurz & Cucurbitaceae & Young fruit \\
\hline Paria & Momordica charantia $L$ & Cucurbitaceae & Young leave \\
\hline Uwi turus & Dioscorea aculeata Roxb. & Dioscoreaceae & Bulb \\
\hline Lampinak & Cnesmone javanica Blume & Euphorbiaceae & Young leave \\
\hline Jawau & Manihot esculenta Crantz & Euphorbiaceae & Young leave \\
\hline Kulat siaw & Hygrocybe conica (Schaeff.: Fries) Kumm & Hygrophoraceae & Fruit body \\
\hline Bawang suna & Allium schoenoprasum $\mathrm{L}$. & Liliaceae & Bulb, leave \\
\hline Jagung belanda & Abelmoschus esculentus (L.) Moench & Malvaceae & Fruit \\
\hline Uru mahamen & Mimosa pudica $\mathrm{L}$. & Mimosaceae/Fabaceae & Young leave \\
\hline Kalamenyu & Ardisia sp. Sw. & Myrsinaceae & Young leave \\
\hline Teken parei & Helminthostachys zeylanica (L.) Hook & Ophioglossaceae & Young leave \\
\hline Katu & Sauropus androgynus (L.) Merr & Phyllanthaceae & Young leave \\
\hline Kulat enyak & Oudemansiella sp. Speg. & Physalacriaceae & Fruit body \\
\hline Kulat baputi & Pleurotus ostreatus (Jacq. ex Fr.) P.Kumm. & Pleurotaceae & Fruit body \\
\hline Kulat danum & Pleurotus sp. (Fr.) P. Kumm. & Pleurotaceae & Fruit body \\
\hline Humba betung & Dendrocalamus asper (Schult. \& Schult. f.) Backer & Poaceae & Young shoot \\
\hline Sarai & Cymbopogon citratus (DC.) Stapf & Poaceae & Inner shoot \\
\hline Kalakai & Stenochlaena palustris (Burm.) Bedd & Polypodiaceae & Young leave \\
\hline Bajei & Ceratopteris thalictroides (L.) Brongn & Pteridaceae & Young leave \\
\hline Taya & Nauclea sp. L. & Rubiaceae & Young leave \\
\hline Kenyem & Lepisanthes alata (Blume) Leenh & Sapindaceae & Fruit \\
\hline Kulat kritip & Schizophyllum commune Fries & Schizophyllaceae & Fruit body \\
\hline Rimbang asem & Solanum ferox $\mathrm{L}$. & Solanaceae & Fruit \\
\hline Terung tanteloh & Solanum mammosum L. & Solanaceae & Fruit \\
\hline Sanggau & Solanum torvum $\mathrm{Sw}$. & Solanaceae & Fruit \\
\hline Kedondong & Spondias pinnata_(L. f.) Kurz & Anacardiaceae & Young leave \\
\hline Henda & Curcuma domestica Val. & Zingiberaceae & Flower \\
\hline Potok & Alpinia sp. Roxb. & Zingiberaceae & Young shoot \\
\hline
\end{tabular}


The various species of mushroom were $P$. ostreatus, Oudemansiella sp., A. auricula, $H$. conica, and $S$. commune. The Pleurotus sp. is a kind of oyster mushrooms, having different texture of the fruit flesh. The mushroom of Auricularia sp. or better known as jelly ear mushroom has pale brown color, while Hygrocybe conica has the red color. The mushrooms are commonly found on decomposed tree trunks. The mushrooms are sold by local people in the marketplace and on the sides of one road that connects the district with other districts. The abundance of a variety of mushroom is strongly influenced by the season. They are usually abundant during the rainy season. Edible mushroom exploration by Nion et al. (2010) reported that the wild Pleurotus sp. and S. commune were abundant in the months from May to July, while Oudemansiella sp. which usually grows on the decaying trunks of rubber trees was found only in the month of May and Auricularia sp. only in November.

The most widely sold vegetables in the market were $S$. palustris and $C$. thalictroides. These vegetables are commonly found on the roadside, agricultural area, in the former area of open land and land burned. Most of the local vegetables are grown wild without cultivation. Rattans (Calamus sp.), for example, are widely spread, and climb the stems of large trees. There are various types of rattan namely bajungan, uwei irit, rua and lepu. The differences are found in stem size and color (white, pink and green). The part plant consumed is young shoot which has bitter taste. Other vegetables that grow wild are $C$. asiaticum, $L$. flava and $M$. pudica that grow wild in peat swamps. This abundance result is similar to that of Irawan et al. (2006).

Species of wild plants which have been cultivated lately are $G$. cochinense, A. esculentus, $H$. zeylanica, A. schoenoprasum, Alpinia sp., S. torvum, S. ferox and $S$. torvum. The fruit vegetable $S$. ferox is a type of Solanum which was originally considered a weed plants, but it is now cultivated by a resident in Berengbengkel Palangkaraya. The round fruit shape of S. ferox is larger than that of $S$. torvum. The fruit is sour and can be consumed either when it is raw (green) or ripe (yellow). According to the local residents, another vegetable which has been cultivated by local residents is $H$. zeylanica. The vegetable is sometimes found under a rubber tree stands, meanwhile Chiu and Chang, (1992) state that $H$. zeylanica is rare plant in lightly shaded region and it is the only species of the genus Helminthostachys. The rhizome of the plant contains antioxidant flavonoids (Huang et al. 2003) and is widely used in Chinese herbal medicine as an antipyretic and antiphlogistic agent (Chiu and Chang 1992). Another wild plant which has been cultivated is $A$. esculentus. This plant is native to Africa and is now grown in many areas such as Asia, Middle East and Southern States of the USA (Calisir et al. 2005; Adelakun et al. 2009; Sengkhamparn et al. 2010), but is little known in Indonesia.

Vegetable consumed only in Central Kalimantan is taro C. esculentum runner. It is a vegetative part (stolon) of taro plant, horizontally growing on top of the ground usually more than $30 \mathrm{~cm}$ long. A single clump of taro plant can have $4-5$ pieces of runner. The more fertile and friable the soil, the more runner comes out, but not all of taro can be consumed due to the itchy-inducing substance.

\section{Ethnobotany}

For the Dayaks people of Central Kalimantan, $S$. palustris is a favorite food. In addition to the distinctive and delicious taste $S$. palustris is also believed to be the drug of youth. It can be stir-fried, boiled, and made into clear soup or just consumed as fresh vegetable. According to Irawan et al. (2006), S. palustris, C. thalictroides and runner of $C$. esculentum can be a good source of iron and folic acid. The vegetables may be given to women during the childbearing and post delivery periods.

For most people of Indonesia, rattan (Calamus sp.) is known as an industrial raw material, mainly for handicrafts and furniture but not so with the Dayaks people in Central Kalimantan. They actually take advantage of young rattan stems commonly called singkah. Rattan is usually cooked with fish, S. ferox, and taro runner. This tasty dish is also quite bitter, so it has the distinctive taste of local cuisine. Meanwhile, Alpinia sp. and M. pudica have a slightly sour taste. Sour taste is believed to reduce the fishy smell of fish when Alpinia sp. cooked and mixed with fish. Likewise, young taya (Nauclea sp.) leaves are usually cooked with pork with a slightly bitter and sour distinctive taste. $G$. cochinense (Irawan et al. 2006) has an ability to absorb bitterness and is frequently used as sweetener. S. torvum (pea eggplant) is cooked with mashed cassava leaves or used by boiling. H. zeylanica is a seasonal plant and the population is not too much. Utilized part of this plant is the young leaves. The vegetable may be stir-fried, made into clear soup, a light coconut milk soup and acidic soup. It is also used by the Dayaks people as a substitute for the flavor in dishes by adding a few pieces of leaves into the dishes. According to local people the vegetable also has medicinal properties. Ethnomedical investigation by Sarker et al. (2012) reported that $H$. zeylanica roots were crushed and added to three finger widths of water and taken thrice on an empty stomach to treated severe fever, red color of urine and pain in the urinary bladder. $G$. cochinense has been reported to be used for treating various types of ailments including diabetes and malaria (Syiem and Lyngdoh 2009).

Some communities in other regions eat taro on the leaves and tubers, but in Central Kalimantan, runner that grows above the ground around the parent plant is also used as a vegetable. The method of cooking is to peel the thin outer skin and then to cut the length of $\pm 4-5 \mathrm{~cm}$, wash, boil in advance to get rid of itchy-inducing substance. Meanwhile A. esculentus commonly named okra is processed to be clear soup or just consumed as fresh vegetables. Adelakun et al. (2009) reported that nutritionally, the richest part of the okra plant was the dried seed. Previously, Odelaye et al. (2003) noted that okra seed could serve as alternate rich sources of oil and protein to both the temperate regions and the tropics. Okra seed oil is also rich in unsaturated fatty acids such as linoleic acid, which is an essential fatty acid in human nutrition. 


\section{Nutrient content}

Table 2 shows the proximate analysis results of some local vegetables in Central Kalimantan. In general, vegetables have a moisture content ranging from $83.91 \%$ to $91.44 \%$, while the ash content was $0.62 \%$ to $1.23 \%$. Table 2 also reveals that $H$. zeylanica leaves had the highest content of protein $(4.50 \mathrm{~g}$ $100 \mathrm{~g}^{-1}$ ) followed by $A$. esculentus fruit $\left(1.94 \mathrm{~g} 100 \mathrm{~g}^{-1}\right)$ and $A$.

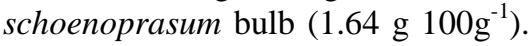
The protein content of $A$. esculentus is smaller than protein content when it is made into flour. Because the roasting is reported to improve flavor and color, the seeds of mature $A$. esculentus are reported to be roasted, ground and used as a coffee substitute in Turkey (Calisir et al. 2005). The range means obtained for roasted seeds protein contents were 42.14-38.10\% (Adelakun et al. 2009). A. esculentus seeds are also reported richer in phenolic compound mainly composed by oligomeric catechins and flavonol derivative (Arapitsas 2008)

The content of carbohydrates in the form of vegetable starch, cellulose and sugar for $H$. zeylanica leaves, A. schoenoprasum bulbs and S. ferox fruit were

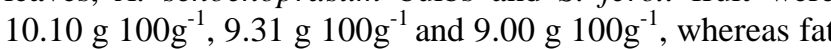

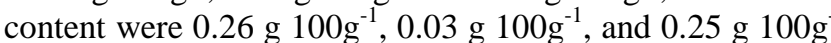
${ }^{1}$, respectively. From the seeds of $S$. ferox, a yellow colored oil has been obtained in $27 \%$ yield. The fatty and found to be palmitic $12.15 \%$, stearic $9.96 \%$ and linoleic acid $38.06 \%$ (Garg and Gupta 2006).

Mineral analysis of some vegetables observed revealed that (Table 3) phosphorus ranged from 11.35 to $97.50 \mathrm{mg}$ $1000 \mathrm{~g}^{-1}$, calcium 268.38 to $1226.57 \mathrm{mg} 1000 \mathrm{~g}^{-1}$, sodium 92.46 to $678.33 \mathrm{mg} 1000 \mathrm{~g}^{-1}$, potassium 1819.36 to 3980.92 mg $1000 \mathrm{~g}^{-1}$ whereas iron content only detected in $H$. zeylanica by $136.72 \mathrm{mg} 1000 \mathrm{~g}^{-1}$. Nutrient-rich foods are vital for proper growth both in adults and children. If we take into account the recommended dietary allowance (RDA) for mineral : phosphorus $700 \mathrm{mg} \mathrm{day}^{-1}$, calcium $1000 \mathrm{mg} \mathrm{day}^{-1}$, iron $8 \mathrm{mg} \mathrm{day}^{-1}$, sodium $1500 \mathrm{mg} \mathrm{day}^{-1}$ and potassium $4700 \mathrm{mg} \mathrm{day}^{-1}$ for adults (Institute of Medicine Food and Nutrition Board, National Academies 2005) some local vegetables can provide 1.7-14\%, 26.9-122.6 \%, 6.13$45.2 \%, 38.7-84.68 \%$ of phosphorus, calcium, sodium and potassium, respectively. Meanwhile, $H$. zeylanica is a good source of iron. Many of the Dayaks traditional vegetables are good sources of iron and have great potential to overcome nutritional anemia among the Indonesian people, especially women. Leaves of $S$. palustris, taro runner and leaves of $C$. thalictroides can become good sources of iron and folic acid. The vegetables may be given to women during the childbearing and post delivery periods (Irawan et al. 2006).

Vegetables account for a small part of our daily caloric intake: however their benefits to health surpass their caloric contribution. The contributory factors are due to the presence of vitamins and provitamins (Ismail et al. 2004). Many vegetables also contain high phenolics that provide a source of dietary anti-oxidants (Kaur and Kapoor 2002). The results of analysis of vitamin C (Table 3) also showed that among vegetables analyzed, $H$. zeylanica had the

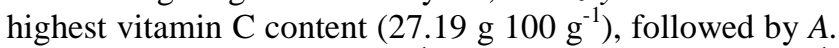

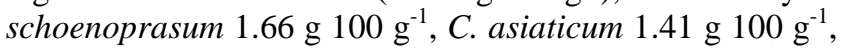

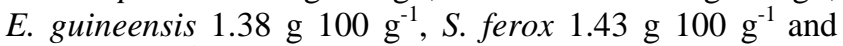

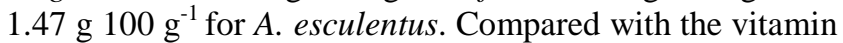
$\mathrm{C}$ content in tomatoes $\left(17.8-19 \mathrm{mg} 100 \mathrm{~g}^{-1}\right)$ and tapioca leaves (77.2-1100 mg $100 \mathrm{~g}^{-1}$ ) (Tee et al. 1988), vitamin C in some local vegetables studied are still higher.

\section{CONCLUSION}

The exploration conducted in three districts found 42 species of local vegetables consumed by the local people of Central Kalimantan. They consume the vegetables by boiling, steaming and eating them fresh. Some vegetables are also believed to have properties to maintain a healthy body from disease. Some vegetables also have potential as sources of nutrients for humans. 


\section{ACKNOWLEDGMENTS}

We would like to thank to Direktorat Jenderal Pendidikan Tinggi Kementerian Pendidikan Kebudayaan Indonesia for granting financial support under Fundamental Grant No. 0541/023-04.1.01/00/2011, and to Cenarung as native Dayak person for his ethnobotanical knowledge of vegetables.

\section{REFERENCES}

Adelakun OE, Oyelade OJ, Ade-Omowaye BIO, Adeyemi IA, Van de Venter M. 2009. Chemical composition and the antioxidative properties of Nigerian okra seed (Abelmochus esculentus Moench) flour. Food Chem Toxicol 47: 1123-1126

AOAC. 1990. Official Methods of Analysis. Association of Official Analytical Chemists. Washington DC.

Arapitsas P. 2008. Identification and quantification of phlyphenolic compounds from okra seeds and skin. Food Chem 110: 1041-1045

Backer CA, Bakhuizen v.d. Brink Jr RC. 1963. Flora of Java. Vol. I. P.Noordhoff, Gronigen.

Backer CA, Bakhuizen v.d. Brink Jr RC. 1965. Flora of Java. Vol. II. P.Noordhoff, Gronigen.

Backer CA, Bakhuizen v.d. Brink Jr RC. 1968. Flora of Java. Vol. III. P.Noordhoff, Gronigen.

Calisir S, Ozcan M, Haciseferogullari H, Yidiz MU. 2005. A study on some physic-chemical properties of Turkey okra (Hibiscus esculenta L.) seeds. J Food Eng 68: 73-78

Chiu NY and Chang KH. 1992. The Illustrated Medicinal Plants of Taiwan. Vol 3. Southern Materials Center Inc. Taipei

Dweba TP and Mearns MA. 2011. Conserving indigenous knowledge as the key to the current and future use of traditional vegetables. Int. J. of Inf. Management 31: 564-571

Garg SK, Gupta DR. 2006. Chemical examination of the seed fat of Solanum ferox L. Eur J Lipid Sci Technol 68 (6): 449-450.

Hendra M. 2002. Utilization of fruits and wild vegetables by Dayak Kenyah of East Kalimantan. [Dissertation]. Bogor Agricultural University, Bogor. [Indonesian]

Huang YL, Yeh PY, Shen CC, Chen CC. 2003. Antioxidant flavonoids from the rhizomes of Helminthostachys zeylanica. Phytochemistry 64: $1277-1283$
Institute of Medicine, Food and Nutrition Board. 2005. Dietary Reference Intakes for Energy, Carbohydrate, Fiber, Fat, Fatty Acids, Cholesterol, Protein, and Amino Acids (Macronutrients). The National Academies Press, Washington, DC. doi:10.17226/10490.

Irawan D, Wijaya CH, Limin SH, Hashidoko Y, Osaki M, Kulu IP. 2006. Ethnobotanical study and nutrient potency of local traditional vegetables in Central Kalimantan. Tropics 15 (4): 441-448

Ismail A, Marjan ZM, Foong CW. 2004. Total antioxidant activity and phenolic content in selected vegetables. Food Chem 87 (4): 581-586

Kaur C and Kapoor HC. 2002. Anti-oxidant activity and total phenolic content of some Asian vegetables. Int J Food Sci Technol 37 (2): 15

Laker MC. 2007. African leafy vegetables in South Africa. Water SA 33 (3): 161-315

MacKinnon K, Hatta G, Halim H, Mangalik A. 2000. The Ecology of Kalimantan. Prenhallindo. Jakarta.

Nion YA, Agus Djaya A, Kadie EM, Lunne, Sumarlan. 2010. Edible mushrooms of Central Kalimantan. Proceeding of Science National Seminar in FKIP-MIPA. Palangka Raya University, Palangka Raya, 7 Agustus 2010 [Indonesian]

Odelaye OJ, Ade-Omowaye BIO, Adeomi VF. 2003. Influence of variety on protein, fat contents and some physical characteristics of okra seed. J Food Eng 57: 111-114

Onyango MOA. 2003. Development and promotion of technologies for sustainable production and utilization of indigenous vegetables for nutrition security and wealth creation in Kenya. In: Urama K, Fancis J, Momanyi M, Ochugboju S, Ominde A, Ozor N, Manners G (eds.) Agricultural Innovations fo Sustainable Development. African Technology Policy Studies Network, Nairobi Kenya

Sarker B, Akther F, Ayman U, Sifa R, Jahan I, Sarker M, Chakma SK, Podder PK, Khatun Z, Rahmatullah M. 2012. Ethnomedicinal investigations among the Sigibe clan of the Khumi tribe of Thanchi sub-district in Bandarban district of Bangladeesh. Amer-Eur J Sustain Agric 6 (4): 378-386

Sengkhamparn N, Sagis LMC, de Vries R, Schols AA, Sajjaanantakul T, Voragen AGJ. 2010. Physicochemical properties of pectins from okra (Abelmochus esculentus (L) Moench. Food Hydrocoll 24: 35-41

Syiem D, Lyngdoh W. 2009. Effect of Gymnopetalum cochinchinensis on blood glucose level in normal and alloxan-induced diabetic mice. Pharmacologyonline 2: 728-738

Tee ES, Young SI, Ho SK, Mizura S. 1988. Determination of vitamin C in fresh fruits and vegetables using the Dye-titration and microfluorometric methods. Pertanika 11 (1): 39-44 